\title{
AN UNUSUAL PRESENTATION OF PILOMATRIXOMA: A CASE REPORT
}

\author{
V.P. Narve ${ }^{1}$, Manish Kumar Sachan ${ }^{2}$, Mohini Vyas ${ }^{3}$, Kavish Jhawar ${ }^{4}$, Freni J.K ${ }^{5}$
}

\section{HOW TO CITE THIS ARTICLE:}

VP Narve, Manish Kumar Sachan, Mohini Vyas, Kavish Jhawar, Freni JK. "An unusual presentation of pilomatrixoma: a case report". Journal of Evolution of Medical and Dental Sciences 2013; Vol2, Issue 33, August 19; Page: 6283-6285.

ABSTRACT: It is an uncommon, harmless, skin lesion derived from hair follicle. Key diagnosis is identification of "densely stained basophilic cells and shadow cells". Complete surgical excision is the treatment with rare chance of complication.

KEY WORDS: Pilomatricoma of preauricular region.

INTRODUCTION: Pilomatrixoma is an uncommon benign circumscribed cutaneous tumour originating from pluripotent precursor of hair matrix cells. ${ }^{3}$ The tumour is usually a deep seated solitary firm nodule with overlying normal epidermis. Majority of these tumours arise during first and second decade of life1.Most common site is head and neck, followed by upper extremities, trunk and lower extremities, never been reported on palms and soles. Overall there is female predominance. $^{3}$ Calcium deposition can occur within the tumours and when present, has been helpful in suggesting the diagnosis at FNAC. ${ }^{1}$ FNAC can help in the diagnosis of pilomatrixoma pre operatively. Typically benign tumour but have a tendency to recur if not completely resected. ${ }^{3}$

CASE REPORT: A $17 \mathrm{yr}$ old female presented with complains of swelling in front of right ear for 2 months and pain over the swelling for 1 month.

0/E:- the swelling was superficial, round in shape, approx. $0.5 \times 0.5 \mathrm{~cm}$ in size, smooth surface, tender to touch and attached to overlying skin, no pus or discharging sinus seen.

She had no other signs and symptoms. Routine lab tests were normal. A preliminary diagnosis of pilomatrixoma was made by FNAC. Excisional biopsy of the lump was performed under LA.

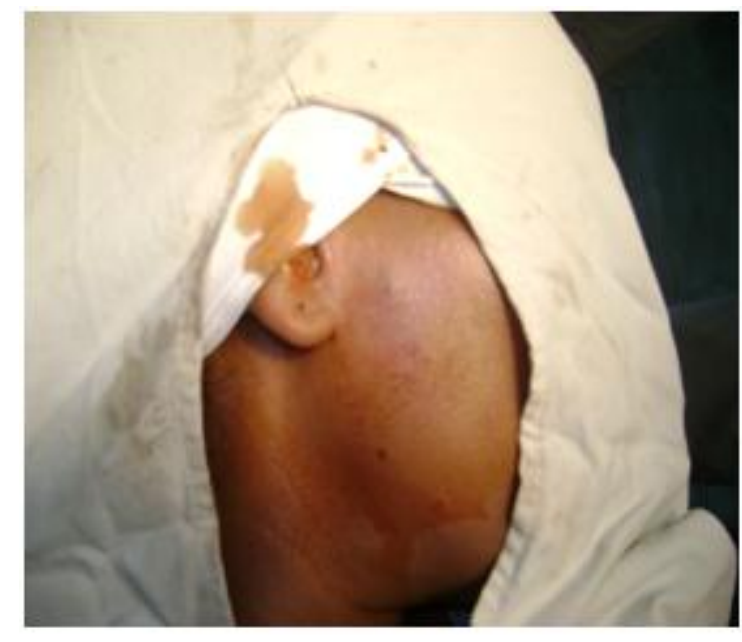

Clinical photograph showing swelling present in preauricular region

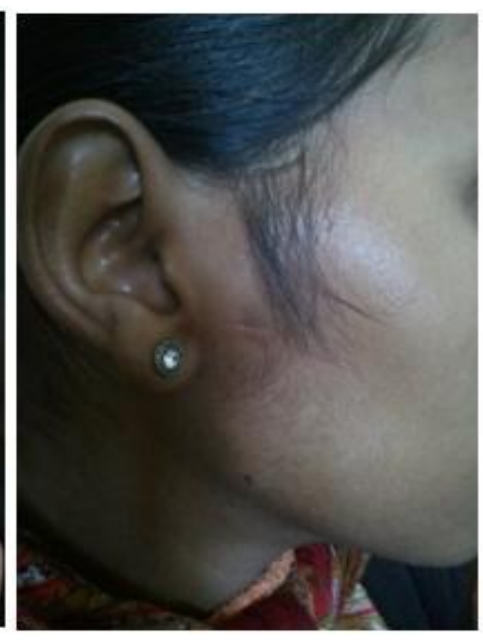

FOLLOW UP 


\section{CASE REPORT}

FNAC:-FNAC revealed presence of ghost cell, calcium deposition, squamous cells with nucleus, foreign body giant cells and basaloid cells in the mass. These findings suggestive of pilomatrixoma.

HISTOPATHOLOGICAL REPORT: Section showed stromal tissue with keratinous shadow cells with no nuclei and are surrounded by mononuclear cell infiltrate predominantly lymphocytes and few plasma cells along with plenty multinucleated giant cells reacting to tumour keratin. Single foci of basaloid cells abruptly changing into keratinous tissue are also seen.

These features are suggestive of benign tumour of epidermal appendages with differentiation towards hair follicle. ( PILOMATRIXOMA).

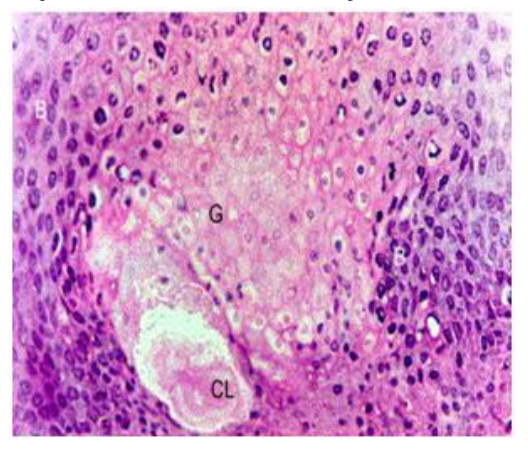

DISCUSSION: Pilomatrixomas are of ectodermal origin and arise from the outer root sheath cells of hair follicle. ${ }^{4}$ Incidence of pilomatrixoma has been reported between $0.03-0.1 \%$. 40-77\% of pilomatrixomas are located in the head and neck region. ${ }^{3}$ Pilomatrixoma is mostly of size $5 \mathrm{~mm}-2 \mathrm{~cm}$, firm, mobile but adherent to skin, slowly growing, usually painless solitary nodule which usually present in subcutaneous tissue. Rarely they can be multiple. ${ }^{2}$ It has been shown that beta catenin mutation with gene map locus 3p22-p21.3 is frequently associated with pilomatrixoma but exact role of this mutation is unknown. ${ }^{3}$ Although as a rule, pilomatrixoma is not hereditary, a few instances of familial occurrence has been reported and in some of the cases the tumour may be associated with myotonic dystrophy, gardner syndrome. Rapid enlargement of pilomatrixoma may occur as a result of hematoma formation. ${ }^{1}$

Fine needle aspiration revealed presence of ghost cells, calcium deposition, squamous cells with nucleus, foreign body giant cells and basaloid cells in the mass. These findings are diagnostic of pilomatrixomas. ${ }^{3}$

Histopathological examination revealed single foci of basaloid cells and shadow cells with no nuclei. With von kossa stain, calcium deposits are found in approximately $75 \%$ of the tumours. ${ }^{1}$

4 distinct morphological stages have been proposed:-

1) Early - small and cystic lesions

2) Fully developed - large and cystic neoplasm

3) Early regressive - foci of basaloid cells, shadow cells and lymphocytic infiltrates with multinucleated giant cells

4) Late regressive - numerous shadow cells, absence of basaloid or inflammatory cells, calcification and ossification may be present. ${ }^{5}$

Complete excision is the preferred treatment, as spontaneous regression has not been described. Malignant transformation are rare. ${ }^{3}$ 
CONSENT: Written informed consent was obtained from the patient for publication of this case report and accompanying images.

FUNDING: None

CONFLICT OF INTEREST: None

ACKNOWLEDGEMENT: We thank Dr. Ritu Nigam, Dr. Shaila Sidam, Dr. R.R. Chaturvedi, Dr. Amit Jain for helping in diagnosis and management of the case. We also thank ethical committee of the hospital for ethical clearance.

\section{REFERENCE:}

1. Lever (Histopathology of skin).

2. Fletcher (Histopathology of tumour).

3. Universal journal of medicine and dentistry Vol.-1 56-58 Aug 12.

4. Tarcilia aprecida da silva, Edgard franco moraes junior Braz dent J (2003) 14(3) 223-226.

5. Ishita Pant, Sanjeev Chandra Joshi etc. dept. of pathology and oncology advanced medical and dental institute, University Sains Malaysia 2010.

\section{AUTHORS:}

1. V.P. Narve

2. Manish Kumar Sachan

3. Mohini Vyas

4. Kavish Jhawar

5. Freni J.K.

\section{PARTICULARS OF CONTRIBUTORS:}

1. Associate Professor \& HOD, Department of Otorhinolaryngology, Gajra Raja Medical College, Gwalior, M.P.

2. $3^{\text {rd }}$ Year Post Graduate Student, Department of Otorhinolaryngology, Gajra Raja Medical College, Gwalior, M.P.

3. $2^{\text {nd }}$ Year Post Graduate Student, Department of Otorhinolaryngology, Gajra Raja Medical College, Gwalior, M.P.

4. $2^{\text {nd }}$ Year Post Graduate Student, Department of Otorhinolaryngology, Gajra Raja Medical College, Gwalior, M.P.
5. $\quad 2^{\text {nd }}$ Year Post Graduate Student, Department of Otorhinolaryngology, Gajra Raja Medical College, Gwalior, M.P.

\section{NAME ADDRESS EMAIL ID OF THE CORRESPONDING AUTHOR:}

Dr. V.P. Narve,

Associate Professor \& HOD,

Department of ENT,

G.R.MC., Gwalior \& JAH (M.P.) - 474009.

Email-drvpnarve@gmail.com

Date of Submission: 08/08/2013.

Date of Peer Review: 10/08/2013.

Date of Acceptance: 10/08/2013.

Date of Publishing: 17/08/2013 